\title{
Klasifikasi "BUKU" (Bank Umum Kegiatan Usaha) dan Determinan Kinerja Keuangan Bank
}

Juwita Citrawati ${ }^{1}$, Nurmala Ahmar ${ }^{2}$

${ }^{1}$ Universitas Pancasila, Jl. Srengseng Sawah, Jagakarsa, Jakarta Selatan, 12640

${ }^{2}$ STIE Perbanas Surabaya, Jl.

INFO ARTIKEL

JEL Classsification:

Keywords:

BUKU Classification,

Return On Asset,

Financial Ratio, Bank

Performance

\section{ABSTRACT}

This study aims to analyze the effect of CAR (Capital Adequacy Ratio), LDR (Loan to Deposit Ratio), NPL (Non Performing Loan) and bank size. The size of the bank is measured by the BUKU classification. Measurements with the BUKU classification (Commercial Banks Business Activities) are still not carried out by many other researchers. The technique of measuring size with BUKU classification is done using a dummy variable. which is measured by the BUKU classification. Measurements with the BUKU classification (Commercial Banks Business Activities), are still not done by many other researchers. The number of samples was analyzed for 96 data years. Testing is done by multiple regression tests. The results showed that CAR, NPL, and $B U K U$ Size had an effect on ROA, and LDR had no effect on ROA. Suggestions for future researchers, regulatory factors that differentiate bank products and services are taken into consideration in influencing bank profitability.

\begin{abstract}
ABSTRAK
Penelitian ini bertujuan untuk menganalisis pengaruh CAR (Capital Adequacy Ratio), LDR (Loan to Deposit Ratio), NPL (Non Performing Loan) dan size bank. Ukuran bank diukur dengan klasifikasi BUKU. Pengukuran dengan klasifikasi BUKU (Bank Umum Kegiatan Usaha) masih belum banyak dilakukan oleh peneliti lain. Teknik pengukuran size dengan klasifikasi BUKU dilakukan dengan menggunakan variabel dummy yang diukur dengan klasifikasi BUKU. Pengukuran dengan klasifikasi BUKU (Bank Umum Kegiatan Usaha) masih belum banyak dilakukan oleh peneliti lain. Jumlah sampel dianalisis sebanyak 96 data tahun. Pengujian dilakukan dengan uji regresi berganda. Hasil penelitian menunjukkan CAR, NPL, dan Ukuran BUKU berpengaruh terhadap ROA, dan LDR tidak berpengaruh terhadap ROA. Saran bagi peneliti selanjutnya, faktor-faktor regulasi yang membedakan produk dan layanan bank dijadikan pertimbangan dalam pengaruh terhadap profitabilitas bank.
\end{abstract}

\section{Pendahuluan}

Tujuan utama berdirinnya suatu badan usaha, baik berbentuk Perseroan Terbatas (PT), Yayasan maupun bentuk-bentuk badan usaha lainnya adalah untuk memperoleh keuntungan.
Keuntungan yang diperoleh tidak saja dipergunakaan untuk membiayai operasi perusahaan, seperti membayar gaji serta biaya-biaya lainnya, akan tetapi juga digunakan untuk ekspansi peru-

*Email Korespondensi: ${ }^{1}$ jwta.citrawati@gmail.com 
sahaan melalui berbagai kegiatan dimasa yang akan datang.

Setiap perusahaan memiliki ciri-ciri tersendiri dan karakteristik sehingga dalam pengelolaannya pun harus disesuaikan dengan ciri dan karakteristik perusahaan tersebut. Salah satu perusahaan yang menjual jasa adalah perusahaan yang bergerak dalam bidang perbankan atau lebih dikenal dengan nama bank (Kasmir,2003:2).

Perbankan mempunyai peran yang sangat vital dalam pencapaian tujuan nasional yang berkaitan dalam peningkatan dan pemerataan taraf hidup masyarakat serta menunjang berjalannya roda perekonomian, penyelenggara transaksi pembayaran, serta alat transmisi kebijakan moneter. Menurut Undang-Undang RI Nomor 10 Tahun 1998 tentang perbankan, yang dimaksud dengan bank adalah badan usaha yang menghimpun dana dari masyarakat dalam bentuk simpanan dan menyalurkannya kepada masyarakat dalam bentuk kredit dan bentuk-bentuk lainnya dalam rangka meningkatkan taraf hidup rakyat banyak. Berdasarkan pengertian tersebut dapat dikemukakan bahwa kegiatan bank selalu berkaitan dengan masalah keuangan yaitu menghimpun dana dan menyalurkan dana. Dengan demikian bank harus menjaga kepercayaan masyarakat dengan menjamin tingkat likuiditas juga beroperasi secara efektif dan efisien untuk mencapai profitabilitas yang tinggi.

Penilaian kinerja keuangan merupakan salah satu faktor yang amat penting bagi perusahaan, tak terkecuali perusahaan perbankan. Ukuran untuk melakukan penilaiaan kinerja keuangan perbankan telah ditetapkan oleh Bank Indonesia melalui Surat Keputusan Direksi Bank Indonesia No.30/277/KEP/DIR tanggal 19 maret 1998 tentang tata cara penilaian Kesehatan Bank Umum. Menurut Almilia (2000), tingkat kesehatan bank dapat dinilai dari beberapa indikator. Salah satu indikator utama yang dijadikan dasar penilaian adalah laporan keuangan bank. Berdasarkan laporan keuangan akan dapat dihitung sejumlah rasio keuangan yang lazim dijadikan dasar penilaian tingkat kesehatan bank. Laporan keuangan bank menunjukan kondisi keuangan bank secara keseluruhan. Dari laporan keuangan akan terbaca bagaimana kondisi bank yang sesungguhnya, termasuk kelemahan dan kekuatan yang dimiliki. Laporan ini juga menunjukkan kinerja manajemen bank selama satu periode. (Kasmir,2000).

Salah satu indikator untuk melihat kinerja keuangan perbankan adalah melalui Return On Asset (ROA). Menurut surat edaran BI No. 3/30 DPNP tanggal 14 Desember 2001, rasio ROA dapat diukur dengan perbandingan antara laba sebelum pajak terhadap total asset (total aktiva). Semakin besar ROA akan menunjukkan kinerja keuangan yang semakin baik, karena tingkat kembalian (return) semakin besar. Kinerja keuangan bank dapat dinilai dari rasio keuangan bank, seperti rasio Capital Adequacy Ratio (CAR), Non Performing Loan (NPL), dan Loan to Deposit Ratio (LDR).

Krisis tahun 1997 ditandai dengan adanya perilaku menyimpang sektor perbankan, lembaga pembiayaan dan dunia usaha yang memanfaatkan perbankan untuk membesarkan group usahanya dengan menghiraukan masyarakat umum. Penyebab inti dari krisis 1997 adalah sistem pembiayaan, investasi, dan deregulasi yang buruk. Bank Indonesia memiliki peran yang sangat vital dalam menjaga dan mengawasi kinerja lembaga keuangan yang sehat terutama perbankan. Penciptaan kinerja perbankan dapat dilakukan melalui adanya mekasnisme pengawasan dan regulasi yang jelas. Kegagalan dalam pengawasan dalam kinerja perbankan dapat menyebabkan ketidakstabilan ekonomi dan keuangan. Hal ini disebabkan karena perbankan memiliki pengaruh yang cukup kuat dalam sistem keuangan Negara. Selain itu, dengan pengawasan dan pengaturan yang dilakukan Bank Indonesia harus disertai dengan penegakan hukum. Hal ini akan meningkatkan kepercayaan masyarakat terhadap sistem keuangan yang ada.

Krisis ekonomi akibat dari adanya kegagalan kebijakan ekonomi makro, kegagalan regulasi maupun kegagalan pasar mendorong 
perlunya kebijakan pemantauan dan penilaian ketahanan sistem keuangan dilakukan dengan dua pendekatan, yaitu makro prudensial yang dilakukan oleh Bank Indonesia (BI), Bank Indonesia hanya akan menjalankan otoritas dibidang kebijakan moneter dan sistem pembayaran dalam menjaga stabilitas sistem keuangan, salah satu fungsinya adalah menjaga stabilitas nilai rupiah. Mikro prudensial dilakukan oleh Otoritas Jasa Keuangan (OJK) yang memiliki wewenang dan tugas dibidang pengawasan dan pembinaan bank. Fungsi BI sebagai lender of the last resort harus memiliki data yang mumpuni tentang sektor keuangan perbankan yang dipegang oleh OJK. BI dan OJK juga harus lebih kuat dalam mengawasi sistem keuangan Indonesia terutama menjelang Asean Economic Community tahun 2015 dimana adanya arus pasar bebas di ASEAN. BI dan OJK harus mampu menciptakan perbankan yang siap bersaing secara global dan mampu ekspansi keluar Indonesia.

Sinyal kesehatan perbankan seperti ketahanan permodalan (CAR) dan fungsi intermediasi perbankan LDR) mengalami peningkatan, tren ketahanan permodalan perbankan terus mengalami peningkatan sejak tahun 2011 sampai dengan tahun 2014, tren peningkatan rasio LDR sejak awal tahun 2010 sampai dengan tahun 2013 adalah dianggap aman bagi bank untuk menjaga keseimbangan antara fungsi intermediasi dan kecukupan likuiditasnya berdasarkan PBI No. 15/7/PBI/2013, namun sempat turun di tahun 2014, tahun 2014 merupakan tahun politik di Indonesia adanya pemilihan umum dan pemilihan Presiden. Kejadian ini juga berpengaruh terhadap rasio NPL pada tahun 2014 yaitu mengalami kenaikan. Berdasarkan sinyal rasio BOPO terlihat efisiensi perbankan menurun di tahun 2014.

Berdasarkan sinyal-sinyal tingkat kesehatan perbankan seperti yang telah dijelaskan di atas selayaknya perbankan dapat memaksimalkan kinerja dalam memperoleh profitabilitas, namun sebaliknya profitabilitas perbankan menurun dan mengalami perlambatan. Berdasarkan hasil analisa empiris inilah yang merupakan suatu fenomena yang membuat penulis melakukan penelitian lebih lanjut.

Research gap penelitian tedahulu timbul karena adannya perbedaan hasil penelitian dari masing-masing peneliti, dan perbedaannya adalah sebagai berikut: Raharjo (2013), Helhel (2014), dan Kusuma dan Haryanto (2016) melakukan penelitian terhadap perbankan di Indonesia, hasilnya rasio CAR berpengaruh signifikan terhadap ROA. Namun, rasio CAR, tidak berpengaruh terhadap ROA menurut Prasanjaya dan Ramantha (2013), Eng (2013), Maria (2015) dan Dewi, Mardani dan Salim (2017).

Penelitian lain dilakukan oleh Raharjo (2013), Prasanjaya dan Ramantha (2013), Kartika (2015) dan Wardiningsih dan Wibowo (2016), penelitian ini menggunakan CAR, NPL, NIM, LDR, BOPO dan ROA perbankan. Hasilnya memperlihatkan ada hubungan yang signifikan antara LDR terhadap ROA perbankan di Indonesia. Sedangkan Eng (2013), Maria (2015) dan Marisa dan Matrodji (2018) dalam penelitiannya LDR berpengaruh tidak signifikan terhadap ROA.

Penelitian lain dilakukan oleh Eng (2013), Raharjo (2013), Helhel (2014), Puspitasari (2015), Dewi, Mardani dan Salim (2017) penelitian ini menggunakan mengungkapkan bahwa NPL memperlihatkan ada hubungan yang signifikan antara NPL terhadap ROA perbankan di Indonesia. Sedangkan Maria (2015), Kusuma dan Haryanto (2016), Marisa dan Matrodji (2018) dan Wardiningsih dan Wibowo (2016) dalam penelitiannya NPL berpengaruh tidak signifikan terhadap ROA. Penelitian dilakukan oleh Kusuma dan Haryanto (2016) memperlihatkan ada hubungan yang signifikan antara Klasifikasi BUKU terhadap ROA perbankan di Indonesia. Sementara Prasanjaya dan Ramantha (2013) memperlihatkan tidak ada hubungan yang signifikan antara SIZE terhadap ROA perbankan di Indonesia. 
2. Telaah Teori dan Pengembangan Hipotesis

Penelitian terkait pengaruh rasio CAR, LDR, NPL dan BUKU terhadap rasio ROA telah banyak dilakukan oleh penelitian sebelumnya. Namun, masih ditemukan inkonsistensi hasil penelitian dari ke 4 variabel yang diuji tersebut. Peneliti melakukan identifikasi kurang lebih 11 hasil penelitian disepanjang tahun 2010 sampai dengan tahun 2017, berbagai hasil penelitian terdahulu tersebut dapat digambarkan pada tabel berikut:

Table 1. Matriks Penelitian tentang Profitabilitas Bank

\begin{tabular}{|c|c|c|c|c|c|c|c|c|c|c|c|}
\hline \multirow[b]{2}{*}{ No. } & \multirow[b]{2}{*}{ Peneliti } & \multicolumn{10}{|c|}{ Variable Independen } \\
\hline & & CAR & LDR & NPL & BOPO & SIZE & NIM & NLTA & BATA & CRDP & INF \\
\hline \multirow[t]{2}{*}{1} & Raharjo ( 2013 ) & SIG - & SIG - & SIG + & SIG - & & SIG + & & & & \\
\hline & Prasanjaya dan & & & & & & & & & & \\
\hline 2 & Ramantha ( 2013 ) & TS & SIG & & SIG & TS & & & & & \\
\hline \multirow[t]{2}{*}{3} & Tan Sau Eng ( 2013) & TS & TS & SIG & TS & & & & & & \\
\hline & Setiyani dan Sudarsi ( & & & & & & & & & & \\
\hline 4 & 2013 ) & TS & SIG & SIG & SIG & SIG & & & & & \\
\hline 5 & Yesim Helhel (2014) & SIG & & SIG & & & & SIG & TS & TS & TS \\
\hline 6 & Mario Ferdinan (2015) & & & & & & & & & & \\
\hline 7 & Pamularsih ( 2014 ) & TS & & SIG & SIG & & SIG & & & & \\
\hline 8 & Maria (2015) & TS & TS & TS & SIG & & SIG & & & & \\
\hline 9 & Ozili ( 2015) & SIG & - & TS & & SIG & & & & & \\
\hline \multirow[t]{3}{*}{10} & Nurintan ( 2016 ) & & TS & TS & SIG & & TS & & & & \\
\hline & Sinung K.P, & & & & & & & & & & \\
\hline & Wardiningsih dan & & & & & & & & & & \\
\hline \multirow[t]{2}{*}{11} & Wibowo ( 2016 ) & & SIG & TS & SIG & & SIG & & & & \\
\hline & Vila dewi, Mardani dan & & & & & & & & & & \\
\hline 13 & Salim ( 2017 ) & TS & & SIG & & & SIG & & & & \\
\hline 14 & Lukitasari kartika (2015) & TS & SIG & TS & SIG & & & & & & \\
\hline
\end{tabular}

Keterangan:

$\begin{array}{lll}\text { CAR } & : \text { Capital Adequacy Ratio } \\ \text { LDR } & : \text { Loan To Deposit Ratio } \\ \text { NPL } & : \text { Non Performing Loan } \\ \text { Size } & : & \text { Ukuran Perusahaan diproksi } \\ & & \text { Klasifikasi BUKU } \\ \text { NIM }: & \text { Net Interest Margin } \\ \text { NLTA : } & \text { Net Loans to Total Asset } \\ \text { BATA : } & \text { Bank Asset to Total Banking Sector } \\ & \text { Asset } \\ \text { CRDP : } & \text { Credit to Deposit Ratio } \\ \text { INF }: & \text { Inflation Rate }\end{array}$

Capital Adequacy Ratio dan Return on Asset

Besarnya nilai rasio CAR dipengaruhi oleh besarnya modal bank dan ATMR, juga dapat dipengaruhi oleh pinjaman debitur. Tingginya nilai CAR dapat diakibatkan oleh penambahan modal atau penurunan ATMR. Penurunan ATMR dapat diakibatkan oleh penurunan dana yang dipinjamkan kepada masyarakat. Penurunan pinjaman kepada masyarakat akan mengakibatkan penurunan income dan akun pinjaman dalam aktiva. Sehingga akan menyebabkan penurunan nilai ROA. Beberapa peneliti sebelumnya yaitu Raharjo (2013), Helhel (2014), dan Kusuma dan Haryanto (2016) dalam penelitiannya menyimpulkan bahwa CAR berpengaruh signifikan terhadap ROA. 
$\mathrm{H}_{1}: \mathrm{CAR}_{\mathrm{t}}$ berpengaruh terhadap $\mathrm{ROA}_{\mathrm{t}+1}$

\section{Non Performing Loan dan Return on Asset}

Besarnya nilai rasio NPL adalah menunjukkan ketidakmampuan debitur untuk membayar pinjamannya atau terdapat kredit yang bermasalah. Seandainya debitur tidak memiliki kemampuan mengembalikan pinjamannya, maka debitur tersebut juga akan tidak memiliki kemampuan membayar bunga bank yang merupakan pendapatan utama bagi perbankan dan berakibat ROA mengalami penurunan. Dari hasil penelitian Eng (2013), Raharjo (2013), Helhel (2014), Puspitasari (2015), Dewi, Mardani dan Salim (2017) menyimpulkan bahwa NPL memiliki pengaruh positif signifikan.

$\mathrm{H}_{2}: \mathrm{NPL}_{\mathrm{t}}$ berpengaruh terhadap $\mathrm{ROA}_{\mathrm{t}+1}$

\section{Loan to Deposit Ratio dan Return on Asset}

Rasio LDR adalah besarnya nilai loan atau pinjaman debitur dibandingkan dengan deposit atau dana yang dihimpun atau disimpan oleh masyarakat dalam bentuk deposito dan tabungan. Kredit yang diberikan kepada debitur individu atau korporasi dilakukan dalam rangka untuk menutupi cost of fund bank yaitu untuk bunga deposito dan bunga tabungan. Makin besarnya jumlah pinjaman yang diberikan oleh bank ke pada debitur maka bank mengharapkan interest income yang diperoleh akan meningkat apabila persentase bunga pinjaman di atas bunga deposito dan tabungan. Dengan meningkatnya interest income bank memberikan pengaruh positif terhadap ROA. Berdasarkan penelitian dari Raharjo (2013), Prasanjaya dan Ramantha (2013), Kartika (2015) dan Wardiningsih dan Wibowo (2016) memberikan kesimpulan dari hasil penelitiannya bahwa Loan Deposit Ratio (LDR) berpengaruh signifikan terhadap ROA.

$\mathrm{H}_{3}$ : Variabel $\mathrm{LDR}_{\mathrm{t}}$ berpengaruh terhadap $\mathrm{ROA}_{\mathrm{t}+1}$

\section{BUKU Bank dan Return on Asset}

BUKU Bank atau Bank Umum Kegiatan Usaha (BUKU) Ukuran perusahaan diukur dengan logaritma natural total asset. Dengan demikian dapat disimpulkan bahwa ukuran perusahaan adalah besarnya kekayaan atau aset yang dimiliki perusahaan, yang diukur dengan menggunakan logaritma natural total asset. Kusuma dan Haryanto (2016) menyimpulkan dalam penelitiannya bahwa BUKU berpengaruh positif dan signifikan terhadap tingkat profitabilitas atau ROA bank.

$\mathrm{H}_{4}$ : BUKU $\mathrm{t}_{\mathrm{t}}$ berpengaruh terhadap $\mathrm{ROA}_{\mathrm{t}+1}$

\section{Metode Penelitian}

Teknik pengukuran size dengan klasifikasi BUKU dilakukan dengan menggunakan variabel dummy. Sampel adalah bank yang terdaftar di Bursa Efek Indonesia dengan tahun amatan 2011 sampai dengan 2016. Jumlah sampel dianalisis sebanyak 96 data tahun. Pengujian dilakukan dengan uji regresi berganda. Uji asumsi klasik dilakukan untuk memenuhi syarat uji regresi terbaik, linier, tidak bias dan dapat diestimasikan. Uji asumsi klasik yang dilakukan mencakup, uji normalitas, heteroskedastiditas, multikolinearitas, dan uji autokorelasi. Hasil uji asumsi klasik menunjukkan bahwa distribusi residual model yang diuji baik, tidak terjadi multikolinearitas, tidak terjadi heteroskedastisitas dan tidak terjadi autokorelasi. Uji model penelitian menggunakan koefisien determinasi dan Uji F. Uji hipotesis didasarkan pada hasil uji t. Kriteria pengujian menggunakan tingkat kesalahan sebesar 5\%. 
Tabel 2. Variabel dan Pengukurannya

\begin{tabular}{|c|c|c|c|c|}
\hline Variable & Definisi & Indikator & Skala & Rujukan \\
\hline $\begin{array}{l}\text { Kinerja } \\
\text { keuangan }(\mathrm{Y})\end{array}$ & $\begin{array}{l}\text { Rasio laba } \\
\text { sebelum pajak } \\
\text { terhadap total } \\
\text { asset }\end{array}$ & $\frac{\underline{\text { Laba Sebelum Pajak }}}{\text { Total Aset }}$ & Rasio & $\begin{array}{l}\text { Raharjo (2013), Prasanjaya } \\
\text { dan Ramantha (2013) }\end{array}$ \\
\hline $\begin{array}{l}\text { Capital } \\
\text { Adequacy } \\
\text { Ratio }\left(\mathrm{X}_{1}\right)\end{array}$ & $\begin{array}{l}\text { Rasio antara } \\
\text { modal sendiri } \\
\text { terhadap aktiva } \\
\text { tertimbang } \\
\text { menurut resiko }\end{array}$ & $\frac{\text { Modal Sendiri }}{\text { ATMR }}$ & Rasio & $\begin{array}{l}\text { Raharjo (2013), Prasanjaya } \\
\text { dan Ramantha (2013) }\end{array}$ \\
\hline $\begin{array}{l}\text { Non Perfoming } \\
\text { Loan }\left(\mathrm{X}_{2}\right)\end{array}$ & $\begin{array}{l}\text { Rasio antara } \\
\text { kredit } \\
\text { bermasalah } \\
\text { terhadap total } \\
\text { kredit }\end{array}$ & $\frac{\text { Kredit Bermasalah-CKPN }}{\text { Total Kredit }}$ & Rasio & $\begin{array}{l}\text { Raharjo (2013), Prasanjaya } \\
\text { dan Ramantha (2013) dan } \\
\text { Dewi, Mardani dan Salim } \\
\text { (2017) }\end{array}$ \\
\hline $\begin{array}{l}\text { Bank Umum } \\
\text { Kegiatan } \\
\text { Usaha }(B U K U) \\
\left(\mathrm{X}_{3}\right)\end{array}$ & & $\begin{array}{l}\text { Ukuran Bank Umum } \\
\text { berdasarkan Modal }\end{array}$ & Rasio & $\begin{array}{l}\text { Nilmawati (2014) dan } \\
\text { Kusuma dan Haryanto } \\
\text { (2016) }\end{array}$ \\
\hline $\begin{array}{l}\text { Loan to } \\
\text { Deposit Ratio } \\
\left(\mathrm{X}_{4}\right)\end{array}$ & $\begin{array}{l}\text { Rasio antara } \\
\text { kredit yang } \\
\text { diberikan } \\
\text { terhadap total } \\
\text { dana pihak } \\
\text { ketiga }\end{array}$ & $\begin{array}{c}\frac{\text { Total Kredit }}{\text { Total Dana Pihak Ketiga }}\end{array}$ & Rasio & $\begin{array}{l}\text { Prasanjaya dan Ramantha } \\
\text { (2013), Raharjo (2013), } \\
\text { Wardiningsih dan Wibowo } \\
\text { (2016) }\end{array}$ \\
\hline
\end{tabular}

\section{Hasil dan Pembahasan}

Analisis data merupakan tahap yang paling penting dalam menyusun sebuah penelitian ilmiah. Terdapat tiga tahap yang dilakukan oleh peneliti untuk menganalisis data yang diperoleh. Pertama, peneliti melakukan analisis deskriptif dengan menjelaskan objek (variabel) penelitian yang diamati. Kedua, peneliti melakukan pengujian hipotesis dengan menjelaskan diterima atau ditolak hipotesis berdasarkan hasil analisis statistika. Ketiga, peneliti melakukan pembahasan atas hasil pengujian yang telah dilakukan.

Return On Asset dari suatu perusahaan diukur dengan kesuksesan perusahaan dan kemampuan menggunakan aktivanya secara produktif, dengan demikian Return On Asset dari suatu perusahaan dapat diketahui dengan memperbandingkan antara laba yang diperoleh dalam suatu periode tertentu dengan jumlah aktiva perusahaan tersebut. Profitabilitas dalam penelitian ini menggunakan ROA. Return On Asset dari suatu perusahaan diukur dengan kesuksesan perusahaan dan kemampuan menggunakan aktivanya secara produktif, dengan demikian Return On Asset dari suatu perusahaan dapat diketahui dengan memperbandingkan antara laba yang diperoleh dalam suatu periode tertentu dengan jumlah aktiva perusahaan tersebut. Berdasarkan tabel 4.3 diatas diketahui Return on Asset (ROA) Bank Konvensional tahun 2011-2015 memiliki ratarata sebesar 2,0834 atau 2,0834\% yang berarti bahwa perusahaan perbankan yang dijadikan sampel dikategorikan cukup baik, Sedangkan nilai standart deviasi yang dimiliki yaitu 1,13923 atau 1,13923\% lebih kecil dibandingkan dengan rata-rata ROA yaitu atau $16,6277 \%$, maka dapat dikatakan bahwa data variabel ROA menunjukkan berdistribusi dengan baik. 
Capital Adequacy Ratio (CAR) Bank Konvensional tahun 2011-2015 memiliki ratarata sebesar 16,6277 atau $16,6277 \%$ yang berarti bahwa perusahaan perbankan yang dijadikan sampel dikategorikan cukup baik, Sedangkan nilai standart deviasi yang dimiliki yaitu 4,34772 atau 4,34772\% lebih kecil dibandingkan dengan rata-rata CAR yaitu atau $16,6277 \%$, maka dapat dikatakan bahwa data variabel CAR menunjukkan berdistribusi dengan baik.

NPL adalah pinjaman yang tidak dapat dibayarkan nasabah dan sehingga bank tidak mendapatkan keuntungan bunga dari debitur. Maksimum NPL yang bank yang sehat adalah 5\% Berdasarkan tabel 4.3 diatas diketahui Non Performing Loan (NPL) Bank Konvensional tahun 2011-2015 memiliki rata-rata sebesar 2,0184 atau $2,0184 \%$ yang berarti bahwa perusahaan perbankan yang dijadikan sampel dikategorikan cukup baik, sedangkan nilai standar deviasi yang dimiliki yaitu 1,0934 atau 1,0934\% lebih kecil dibandingkan dengan rata-rata NPL yaitu atau 2,0184\%, maka dapat dikatakan bahwa data variabel NPL menunjukkan berdistribusi dengan baik.

LDR merupakan rasio yang merupakan perbandingan total kredit terhadap dana pihak ketiga (DPK) yang dihimpun oleh bank. Rasio ini akan menunjukkan tingkat kemampuan bank dalam menyalurkan dananya yang berasal dari masyarakat (berupa: giro, tabungan, deposito berjangka, sertifikat deposito berjangka dan kewajiban segera lainnya) dalam bentuk kredit. Berdasarkan tabel 4.3 diatas diketahui Loan To Deposit Ratio (LDR) Bank Konvensional tahun 2011-2015 memiliki rata-rata sebesar 83,353 atau $83,353 \%$ yang berarti bahwa perusahaan perbankan yang dijadikan sampel dikategorikan cukup baik, Sedangkan nilai standar deviasi yang dimiliki yaitu 14,33089 atau 14,33089\% lebih kecil dibandingkan dengan rata-rata LDR yaitu atau $83,353 \%$, maka dapat dikatakan bahwa data variabel LDR menunjukkan berdistribusi dengan baik.
Nilai BUKU berdasarkan pengujian ROA, CAR, NPL Dan LDR pada Bank Konvensional tahun 2011-2015 memiliki rata-rata terbesar pada BUKU 3 sebanyak 36 bank dari total 98 bank. Hasil pengujiannya bank yang masuk kategori BUKU 3 lebih tinggi dibanding bank pada kategori BUKU 1. BUKU 3 adalah bank dengan modal inti antara Rp5 triliun - Rp30 triliun. Bank BUKU 3 bisa melakukan seluruh kegiatan produk atau aktivitas Bank BUKU 2 secara lebih luas. Selain itu, bank BUKU 3 juga sudah dapat melakukan penyertaan $25 \%$ pada lembaga keuangan di dalam dan luar negeri terbatas di kawasan Asia. Kondisi ini menyebabkan bank dengan kelompok buku 3 memiliki peluang mendapatkan laba lebiih besar dibanding BUKU 1. Berikut adalah hasil pengujian hipotesis.

Tabel 1. Hasil Pengujian Hipotesis

\begin{tabular}{lrrr}
\hline Keterangan & Koefisien & t-hitung & Sig-t \\
\hline (Constant) & 2,111 & 3,492 & 0,001 \\
*CAR (t) $^{2}$ & $-0,041$ & $-2,234$ & 0,028 \\
*NPL (t) & $-0,186$ & $-2,442$ & 0,017 \\
*LDR (t) & 0,003 & 0,445 & 0,657 \\
BK02 & 0,222 & 0,755 & 0,452 \\
BK03 & 0,745 & 2,442 & 0,017 \\
BK04 & 2,302 & 7,645 & 0,000 \\
R-square & 0,575 & & \\
Adj-R Square & 0,547 & & \\
F-hitung & 20,522 & & \\
Sig & 0,000 & & \\
\hline
\end{tabular}

\section{Pengaruh Capital Adequacy Ratio (CAR) Terhadap Return On Asset (ROA)}

CAR adalah rasio kecukupan modal minimum suatu bank. CAR diatur oleh BIS (Bank for International Settlements) merupakan suatu organisasi membuat peraturan dan berlaku secara international. Pengaturan CAR dalam BIS berdasarkan Bassel 1 menyebutkan bahwa rasio kecukupan pemenuhan modal minimum 
diharuskan diwajibkan sebesar $8 \%$ (Bank Indonesia). Rasio CAR merupakan indikasi yang harus diperhitungkan untuk menilai perbankan yang berisiko dan sebagaipenyangga kemampuan bank memenuhi seluruh kewajibannya apabila kemungkinan terjadinya kerugian. Untuk bank memiliki CAR kurang dari 8\%, maka bank tersebut dapat dikategorikan memiliki risiko sangat tinggi. Sebaliknya semakin tinggi nilai CAR suatu bank, memperlihatkan ketersediaan sejumlah dana sebagai penyangga semakin besarnya kemampuan bank memenuhi seluruh kewajiban apabila terjadinya kerugian. Untuk perhitungan CAR Bank Indonesia merumuskan perhitungan dengan membandingkan modal dengan Aktiva Tertimbang Menurut Risiko (ATMR). Perhitungan Modal dan Aktiva Tertimbang Menurut Risiko dilakukan berdasarkan ketentuan Kewajiban Penyediaan Modal Minimum yang berlaku.

Hasil penelitian diperoleh CAR berpengaruh signifikan terhadap ROA dan CAR menujukkan hubungan negatif terhadap ROA. Pengaruh negatif yang ditunjukkan oleh CAR mengindikasikan bahwa apabila CAR mengalami kenaikan 1 satuan, maka ROA tidak akan mengalami kenaikan 1 satuan, dan sebaliknya apabila CAR mengalami penurunan 1 satuan, ROA tidak akan menurun 1 satuan. Semakin besar CAR mengindikasikan Modal yang dimiliki maka ROA meningkat, sehingga menambah kemampuan bank konvensional dalam menyalurkan modalnya. Sebaliknya, semakin kecil CAR mengidentifikasi modal yang dimiliki maka ROA mengalami penurunan. Sehingga hal tersebut akan mengurangi kemampuan bank konvensional dalam menyalurkan modalnya.

\section{Pengaruh Non Performing Loan (NPL) Terhadap Return On Asset (ROA)}

NPL adalah pinjaman yang tidak dapat dibayarkan nasabah dan sehingga bank tidak mendapatkan keuntungan bunga dari debitur. Maksimum NPL yang bank yang sehat adalah
5\% (Rose dan Hudgins, 2006:151)

Menghitung rasio NPL yaitu membagi total non-performing loan dengan total loan outstanding, yaitu total pinjaman yang sedang berada ditangan peminjam atau debitur dalam satuan persentase. Semakin tinggi nilai rasio NPL mencerminkan kinerja bank tidak baik sebagai akibat nilai kredit atau pinjaman sebagai akibat nasabah peminjam tidak dapat memenuhi kewajibannya untuk membayar pinjaman. Sebaliknya semakin rendah nilai rasio NPL, semakin baik kinerja bank karena dapat mengatasi atau mengurangi terjadinya gagal bayar atau ketidakmampuan nasabah atau debitur memenuhi kewajiban pembayaran terhadap kredit atau pinjaman yang diberikan kepadanya.

Hasil penelitian diperoleh NPL berpengaruh signifikan terhadap ROA. Hal ini mengindikasikan bahwa perubahan yang terjadi terhadap variabel NPL akan berpengaruh signifikan terhadap ROA dan hasil uji menunjukkan nilai yang negatif. Pengaruh negatif yang ditunjukkan oleh NPL mengindikasikan bahwa apabila NPL mengalami kenaikan 1 satuan, maka ROA tidak akan mengalami kenaikan 1 satuan, dan sebaliknya apabila NPL mengalami penurunan 1 satuan, ROA tidak akan menurun 1 satuan. Non Performing Loan (NPL) atau kredit bermasalah merupakan salah satu indikator kunci untuk menilai kinerja fungsi bank. Jika kredit bermasalah semakin tinggi maka profitabilitas semakin rendah. Sebaliknya, semakin kecil NPL mengidentifikasi profitabilitas ROA mengalami peningkatan. Hal ini menggambarkan $\mathrm{H} 2$ yang menyatakan bahwa NPL berpengaruh yang Negatif terhadap ROA yang berarti $\mathrm{H} 2$ yang diajukan diterima.

\section{Pengaruh Loan To Deposit Ratio (LDR) Terhadap Return On Asset (ROA)}

Kegiatan utama perbankan adalah menyimpan dana yang disetorkan oleh masyarakat kemudian digunakan untuk kegiatan usaha utamanya yaitu memberikan pinjaman 
kepada pihak yang memerlukan. Sehingga interest atau bunga menjadi pendapatan utama bank. Adanya beberapa risiko terhadap kegiatan memberikan pinjaman tersebut, kemungkinan adanya gagal bayar dari pihak peminjam atau debitur. Untuk itulah bank perlu mengukur kemampuan calon peminjam atau debitur sebelum memberikan pinjaman. Kriteria penilaian yang umum yang seharusnya dilakukan oleh bank untuk mendapatkan nasabah yang selayaknya diberikan kedit dapat dilakukan dengan analisa $5 \mathrm{C}$ dan 7P.

LDR adalah rasio keuangan yang mengukur tingkat kesehatan perbankan berdasarkan banyaknya pinjaman yang diberikan bank kepada masyarakat dibandingkan dengan jumlah deposit yang disetorkan masyarakat dan modal bank itu sendiri. Rasio ini dinyatakan dalam persentase. Kredit atau pinjaman yang diberikan bank dilakukan oleh pihak bank menutupi cost of fund dari bunga deposito dan tabungan. LDR yang tinggi atau pemberian pinjaman dalam jumlah besar, diharapkan dapat menutup cost of fund dan memberikan profit kepada pihak bank dari bunga pinjaman. Namun dalam hal ini pemerintah Indonesia mengatur jumlah maksimal rasio LDR setiap bank sebesar $110 \%$. Apabila suatu bank memiliki rasio LDR di atas jumlah maksimal yang telah ditentukan oleh pemerintah, dapat disimpulkan tingkat kesehatan bank tidak baik karena memberikan pinjaman dalam jumlah yang terlalu banyak Narayana (2013). Apabila rendahnya intermediasi yang dilakukan oleh perbankan di Indonesia dikarenakan terlalu berhati-hati dalam memberikan kredit atau risk averse dapat mengakibatkan rasio LDR rendah.

Hasil penelitian diperoleh bahwa LDR tidak berpengaruh signifikan terhadap perubahan ROA. Hal ini mengindikasikan bahwa perubahan yang terjadi terhadap variabel LDR tidak akan berpengaruh signifikan terhadap ROA. Koefisien LDR menunjukkan hubungan yang positif terhadap ROA. Pengaruh positif yang ditunjukkan oleh LDR mengindikasikan bahwa apabila LDR mengalami kenaikan 1 satuan, maka ROA akan mengalami kenaikan sebesar 1 satuan, dan sebaliknya apabila LDR mengalami penurunan 1 satuan, maka ROA akan mengalami penurunan 1 satuan. Ketika LDR naik seharusnya ROA juga naik, karena ketika kredit yang diberikan oleh bank tinggi dan tidak bermasalah makan pendapatan bunga atas kredit yang disalurkan bank semakin besar. Hal ini menggambarkan $\mathrm{H} 3$ yang menyatakan bahwa LDR tidak mempunyai pengaruh yang positif terhadap ROA yang berarti H3 yang diajukan diterima.

\section{Pengaruh SIZE-BUKU Terhadap Return On Asset (ROA)}

BUKU 2 tidak berpengaruh signifikan terhadap ROA. Hal ini mengindikasikan bahwa perubahan yang terjadi terhadap variabel BUKU 2 akan tidak berpengaruh signifikan terhadap ROA. BUKU 2 berhubungan positif terhadap ROA dan Pengaruh positif yang ditunjukkan oleh BUKU 2 mengindikasikan bahwa BUKU 2 mengalami kenaikan, maka ROA akan mengalami kenaikan dan sebaliknya apabila BUKU 2 mengalami penurunan, maka ROA akan mengalami penurunan. Berdasarkan hasil pengujian nilai ROA bank yang masuk kategori BUKU 2 lebih tinggi 9,1\% dibanding bank pada kategori BUKU 1. BUKU 2 adalah bank dengan modal inti antara $R p 1$ triliun - Rp 5 triliun. Bank BUKU 2 bisa melakukan seluruh kegiatan produk atau aktivitas Bank BUKU 1 secara lebih luas. Kondisi ini menyebabkan bank dengan kelompok buku 2 memiliki peluang mendapatkan laba lebih besar dibanding BUKU 1.

Pada variable BUKU 3 berpengaruh signifikan terhadap ROA. Hal ini mengindikasikan bahwa perubahan yang terjadi terhadap variabel BUKU 3 akan berpengaruh signifikan terhadap ROA. BUKU 3 berhubungan positif terhadap ROA. Pengaruh positif yang ditunjukkan oleh BUKU 3 mengindikasikan bahwa apabila BUKU 3 mengalami kenaikan 1 satuan, maka ROA akan mengalami kenaikan 
1 satuan dan sebaliknya apabila BUKU 3 mengalami penurunan 1 satuan, maka ROA akan mengalami penurunan 1 satuan. Berdasarkan hasil pengujian nilai ROA bank yang masuk kategori BUKU 3 lebih tinggi 31,7\% dibanding bank pada kategori BUKU 1. BUKU 3 adalah bank dengan modal inti antara Rp5 triliun - Rp30 triliun. Bank BUKU 3 bisa melakukan seluruh kegiatan produk atau aktivitas Bank BUKU 2 secara lebih luas. Selain itu, bank BUKU 3 juga sudah dapat melakukan penyertaan $25 \%$ pada lembaga keuangan di dalam dan luar negeri terbatas di kawasan Asia. Kondisi ini menyebabkan bank dengan kelompok buku 3 memiliki peluang mendapatkan laba lebih besar dibanding BUKU 1.

Pada variabel BUKU 4 diketahui SIZE BUKU 4 berpengaruh signifikan terhadap ROA. Hal ini mengindikasikan bahwa perubahan yang terjadi terhadap variabel BUKU 4 akan berpengaruh signifikan terhadap ROA dan berhubungan positif. Pengaruh positif yang ditunjukkan oleh BUKU 4 mengindikasikan bahwa BUKU 4 mengalami kenaikan 1 satuan, maka ROA akan mengalami kenaikan 1 satuan dan sebaliknya apabila BUKU 4 mengalami penurunan 1 satuan, maka ROA akan mengalami penurunan 1 satuan. Berdasarkan hasil pengujian nilai ROA bank yang masuk kategori BUKU 4 lebih tinggi $81.9 \%$ dibanding bank pada kategori BUKU 1 (nilai ROA BUKU 4 lebih tinggi $81,9 \%$ dibanding BUKU 1). Selain hak yang diberikan kepada BUKU 3 itu, bank BUKU 4 juga dapat melakukan penyertaan sebesar 35\% pada lembaga keuangan di dalam dan luar negeri dengan cakupan wilayah international worldwide sehingga profitabilitasnya jauh lebih tinggi dibandingkan kelompok bank BUKU 1.

\section{Simpulan, Keterbatasan dan Saran}

Penelitian ini bertujuan untuk menganalisis pengaruh CAR (Capital Adequacy Ratio), LDR (Loan to Deposit Ratio), NPL (Non Performing Loan) dan size bank. Ukuran bank diukur dengan klasifikasi BUKU. Pengukuran dengan klasifikasi BUKU (Bank Umum Kegiatan Usaha) masih belum banyak dilakukan oleh peneliti lain. Teknik pengukuran size dengan klasifikasi BUKU dilakukan dengan menggunakan variabel dummy. Sampel adalah bank yang terdaftar di Bursa Efek Indonesia dengan tahun amatan 2011 sampai dengan 2016. Jumlah sampel dianalisis sebanyak 96 data tahun. Pengujian dilakukan dengan uji regresi berganda. Uji asumsi klasik dilakukan untuk memenuhi syarat uji regresi terbaik, linier, tidak bias dan dapat diestimasikan. Uji asumsi klasik yang dilakukan mencakup, uji normalitas, heteroskedastiditas, multikolinearitas, dan uji autokorelasi. Hasil uji asumsi klasik menunjukkan bahwa distribusi residual model yang diuji baik, tidak terjadi multikolinearitas, tidak terjadi heteroskedastisitas dan tidak terjadi autokorelasi. Ukuran Bank terbukti berpengaruh terhadap ROA. Ukuran bank dilakukan dengan teknik dummy variable dengan menggunakan klasifikasi BUKU 1 sebagai dasar perbandingan. Hasil pengujian menunjukkan CAR, NPL, dan Ukuran BUKU berpengaruh terhadap ROA, dan LDR tidak berpengaruh terhadap ROA. Nilai ROA bank yang masuk kategori BUKU 3 dan BUKU 4 lebih tinggi dibanding bank pada kategori BUKU 1. Selain hak yang diberikan kepada BUKU 3 itu, bank BUKU 4 juga dapat melakukan penyertaan sebesar 35\% pada lembaga keuangan di dalam dan luar negeri dengan cakupan wilayah international worldwide sehingga profitabilitasnya jauh lebih tinggi dibandingkan bank BUKU 1.

Penelitian ini tidak melakukan pengujian untuk masing-masing kelompok buku. Penelitian juga tidak mempertimbangkan batasan-batasan usaha dan aktivitas yang melekat pada masingmasing bank berdasarkan kelompok BUKU, sementara ada beberapa kebijakan aktivitas bisnis yang berbeda, misalnya besaran izin penyertaan pada lembaga keuangan dan target penyaluran kredit atau pembiayaan produktif kepada UMKM. Perbedaan ini diduga berdampak pada kemampuan menghasilkan laba (profitabilitas). 
Saran bagi peneliti selanjutnya, faktor-faktor regulasi yang membedakan produk dan layanan bank dijadikan pertimbangan dalam pengaruh terhadap profitabilitas bank. Peneliti selanjutnya juga melakukan pengujian yang berbeda untuk masing-masing kelompok buku, sehingga dapat diketahui dan dianalisis pengaruh pada masingmasing kelompok BUKU.

\section{Daftar Referensi}

Adityantoro, Y. W. K., \&Rahardjo, S. N. (2013). Faktor-Faktor Yang Mempengaruhi Profitabilitas Corresponding Author Perbankan Di Indonesia. Diponegoro Journal of Accounting, 634-645.

Almilia, L. S., \&Herdiningtyas, W. (2005). Analisis Rasio CAMEL terhadap prediksi kondisi bermasalah pada lembaga perbankan periode 2000-2002. Jurnal Akuntansi dan keuangan, 7(2), 131-147.

Daniel Sinung, K. P., Wardiningsih, S. S., \&Wibowo, E. (2016). Analisis Pengaruh Nim, Bopo, Ldr Dan Npl Terhadap Profitabilitas Pada Bank Pemerintah Dan Bank Umum Swasta Nasional Di Bursa Efek Indonesia. Jurnal Ekonomi dan Kewirausahaan, 16(1).

Dewi, N. V., Mardani, R. M., \& Salim, M. A. (2017). Pengaruh CAR, NPL, NIM, dan Bopo Terhadap Profitabilitas Perbankan (Studi Kasus pada Bank Umum Yang terdaftar di Bursa Efek Indonesia Tahun 2012-2015). Jurnal Ilmiah Riset Manajemen, 6(01).

Ediningsih, S. I., Nilmawati, N., \&Sukendro, J. (2014). Utang Dan Pengaruhnya Terhadap Kinerja Perusahaan. Jurnal Keuangan dan Perbankan, 18(1).

Eng, T. S. (2013). Pengaruh NIM, BOPO, LDR, NPL \& CAR Terhadap Roa Bank Internasional Dan Bank Nasional Go Public Periode 2007-2011. Jurnal dinamika manajemen, 1(3).

Helhel, Y. (2015). Evaluating The Performance of the Commercial Banks In Georgia. Research
Journal of Finance and Accounting, 5, 146156.

Kusuma, E. C., \& Haryanto, A. M. (2016). Analisis Pengaruh Variabel Kinerja Bank (Car, Roa, Bopo Dan Ldr), Serta Pertumbuhan Kredit Dan Kualitas Kredit Terhadap Non Performing Loan (Npl) Studi pada Bank Umum Konvensional di Indonesia Secara Kuartal Tahun 20132015 (Doctoral dissertation, Fakultas Ekonomika dan Bisnis).

Lukitasari, Y. P., \& Kartika, A. (2015). Analisis Pengaruh Dana Pihak Ketiga, BOPO, CAR, LDR dan NPL terhadap Kinerja Keuangan Pada Sektor Perbankan yang terdaftar di Bursa Efek Indonesia. INFOKAM, 11(4).

Maria, A. (2015). Pengaruh CAR, BOPO, NIM, NPL, dan LDR Terhadap ROA: Studi Kasus pada 10 Bank Terbaik di Indonesia Periode 2007-2011. CALYPTRA, 4(1), 1-19.

Marisa, L., \&Matrodji, M. (2018). The Effect Of Non-Performing Loan, Capital Adequacy Ratio, Loan To Deposit Ratio And Operating Expenses To Operating Income On Deposit Portfolio Of National Social Security On Employment (Bpjs Ketenagakerjaan) For Period Of 2015-2017.

Narayana, I. P. G. (2013). Pengaruh Perputaran Kas, Loan To Deposit Ratio, Tingkat Permodalan Dan Levergae Terhadap Profitabilitas Bank Perkreditan Rakyat Sekota Denpasar Periode 20092011. E-Jurnal Akuntansi, 334-350.

Prasanjaya, A. Y., \& Ramantha, I. W. (2013). Analisis pengaruh rasio CAR, BOPO, LDR dan ukuran perusahaan terhadap profitabilitas bank yang terdaftar di BEI. E-Jurnal Akuntansi, 230-245.

Puspitasari, E. (2015). Analisis FaktorFaktor Yang Mempengaruhi Net Interest Margin pada Bank-Bank Umum Di Indonesia. Jurnal Ilmu Manajemen (JIM), 2(4).

Rose, J. B. G. (1709). Toward a critical race theory of evidence. HARV. L. REV, (1993). 
